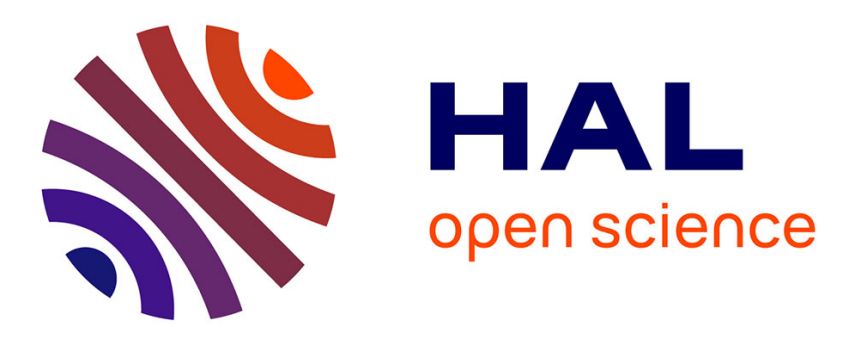

\title{
Phosphine-Mediated Bioconjugation of the 3'-End of RNA
}

\author{
Camélia Kitoun, Matthieu Fonvielle, Nicolas Sakkas, Manon Lefresne, Fabiola \\ Djago, Quentin Blancart Remaury, Pauline Poinot, Michel Arthur, Mélanie \\ Etheve-Quelquejeu, Laura Iannazzo
}

\section{To cite this version:}

Camélia Kitoun, Matthieu Fonvielle, Nicolas Sakkas, Manon Lefresne, Fabiola Djago, et al.. Phosphine-Mediated Bioconjugation of the 3'-End of RNA. Organic Letters, 2020, 22 (20), pp.80348038. 10.1021/acs.orglett.0c02982 . hal-02996863

\section{HAL Id: hal-02996863 https://hal.science/hal-02996863}

Submitted on 11 Dec 2020

HAL is a multi-disciplinary open access archive for the deposit and dissemination of scientific research documents, whether they are published or not. The documents may come from teaching and research institutions in France or abroad, or from public or private research centers.
L'archive ouverte pluridisciplinaire HAL, est destinée au dépôt et à la diffusion de documents scientifiques de niveau recherche, publiés ou non, émanant des établissements d'enseignement et de recherche français ou étrangers, des laboratoires publics ou privés. 


\title{
Phosphine-Mediated Bioconjugation of the 3'-end of RNA
}

\author{
Camélia Kitoun, ${ }^{\dagger}$ Matthieu Fonvielle, ${ }^{\ddagger}$ Nicolas Sakkas, ${ }^{\dagger}$ Manon Lefresne, ${ }^{\dagger}$ Fabiola Djago,,${ }^{\circledR}$ Quentin Blancart Re- \\ maury, ${ }^{\S}$ Pauline Poinot, ${ }^{\S}$ Michel Arthur, ${ }^{\ddagger}$ Mélanie Etheve-Quelquejeu, ${ }^{*+}$ Laura Iannazzo ${ }^{*+}$ \\ + Université de Paris, UMR CNRS 8601, Laboratoire de Chimie et Biochimie Pharmacologiques et Toxicologiques, F-75006 Paris, \\ France. \\ ${ }^{\ddagger}$ INSERM, Sorbonne Université, Université de Paris, Centre de Recherche des Cordeliers (CRC), F-75006, Paris, France. \\ ${ }^{\S}$ Institut de Chimie des Milieux et Matériaux de Poitiers IC2MP, Université de Poitiers, UMR 7285, 86073, Poitiers, France.
}

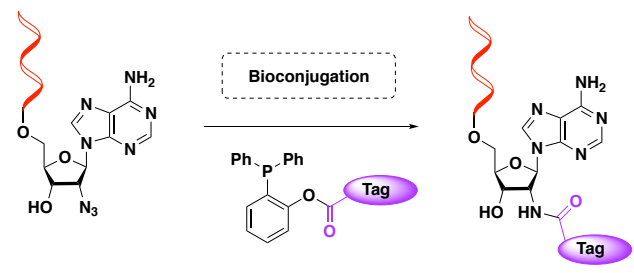

\begin{abstract}
Staudinger ligation is an attractive bioorthogonal reaction which has been widely used to tag proteins, carbohydrates and nucleic acids. Here, we explore the traceless variant of the Staudinger ligation for 3'-end modification of oligoribonucleotides. An azido-containing dinucleotide was used to study the ligation. Nine phosphines containing reactive groups, affinity purification tags or photo-switch probes have been successfully obtained. The corresponding modified dinucleotides were synthesized and characterized by LC/MS. Mechanistic interpretations of the reaction are proposed, in particular, the unprecedented formation of an oxazaphospholane nucleotide derivative, which was favored by the vicinal position of 2'- $\mathrm{N}_{3}$ and 3'-OH functional groups on the terminal ribose has been observed. The post-functionalization of a 24-nt RNA with a photoactivable tag is also reported.
\end{abstract}

Bioconjugation reactions ${ }^{1}$ developed in the last decade enabled the chemical labeling of biomolecules to enrich their functions and properties. Owing the complexity of the biomolecules, due to the presence of reactive groups and their sensitivity to non-physiological $\mathrm{pH}$ or temperature, the bioconjugation reactions have to be chemoand regio-selective, and compatible with nearly physiological conditions in aqueous media. One strategy to enhance the selectivity of a bioconjugation reaction is to first install a unique functional group onto the biomolecule, and then use site-selective type reactions to covalently link the desired tags. A number of site-selective reactions targeting non-native functional groups of biomolecules have been reported so far: i) the condensation between a carbonyl and hydrazines, hydrazides or alkoxyamines; ${ }^{2}$ ii) metal-mediated reactions, such as Alkyne-Azide Cycloadditions (CuAAC or NiAAC), ${ }^{3}$ Sydnone-Alkyne Cycloaddition (CuSAC), ${ }^{4}$ or Palladium-Catalyzed Cross-Coupling Reactions; ${ }^{5}$ iii) strained-promoted cycloadditions, such as dipolar cycloadditions with constrainted alkynes (SPAAC) ${ }^{6}$ or Inverse Electron Demand Diels-Alder reactions (IEDDA); ${ }^{7}$ iv) photoclick reactions, ${ }^{8}$ and finally v) chemical ligation such as Native Chemical Ligation (NCL) ${ }^{9}$ or Staudinger ligation. ${ }^{10}$ The latter reaction is an attractive bioorthogonal conjugation reaction, especially for in vitro and in vivo applications, due to the absence of a metal catalyst and to its capacity to form native amide bond between the tag and the biomolecule. The traceless variant of the Staudinger ligation, independently developed by Raines ${ }^{11}$ and Bertozzi, ${ }^{12}$ is even more interesting, since it leads to the elimination of the phosphine oxide from the final product. These new phosphines developed by Bertozzi and coworkers, ${ }^{12}$ contain an acyl component, which is attached through a cleavable linkage (an ester bond) at the ortho-position of the aryl group of the phenylphosphine. These reagents have been designed to avoid the oxidation of the phosphine under ambient conditions, to introduce conformational rigidity and to promote a six-membered transition state during the acyl transfer. To access a transition state with a smaller ring, Raines and co-workers replaced the $O$-phenyl group by a single methylene moiety and increased the yield of the traceless ligation to couple peptides and azides. ${ }^{13}$ This methodology has been employed for the bioconjugation of polysaccharides, ${ }^{14}$ peptides, ${ }^{15}$ or proteins ${ }^{16}$ Application of the Staudinger-type ligation to nucleoside or nucleotide modification has been mostly restricted to the synthesis of puromycin analogues, ${ }^{17}$ the functionalization with fluorescent probes ${ }^{18}$ and the introduction of affinity purification tags. ${ }^{19}$ The application of the traceless version of the Staudinger ligation has been even more restricted, and, to the best of our knowledge, only reported for the functionalization of a protected 5'-azido-2'-deoxyadenosine. ${ }^{12}$ Since chemistry driven studies of the biological role of RNAs requires new synthetic methodologies to modify their structures, and because no example depicts the modification of RNA by traceless Staudinger ligation, we decided to explore this site-selective reaction as a post-synthetic methodology for the functionalization of RNAs with a variety of functional groups.

Our strategy to access to functionalized RNA relies on the enzymatic ligation of a 5'-phosphorylated dinucleotides (pdC-pA) to an oligoribonuleotide by the T4 RNA ligase. The presence of a 2'-deoxycytidine at the 5 ' position of the dinucleotide facilitates its synthesis and is compatible with the specificity of the T4 RNA ligase. The presence of a 2'-deoxynucleotide at the penultimate position of the ligation product was previously reported to have little impact on the biological function of the final RNA. ${ }^{20}$ To study the bioconjugation of the 3'-terminal RNA position, we selected as a model, the dinucleotide 1 containing an azido group at the 2 ' position of the terminal 
adenosine. The second partner of the reaction was the tag-substituted phosphine. Among the modified phosphine reagents developed in the literature for the traceless Staudinger ligation, we choose phenolic ester $\mathbf{2} \mathbf{a}$ and alkyl thioester $\mathbf{3}$ since they were reported to provide highest ligation yields. ${ }^{21}$

When dinucleotide 1 was treated in presence of 10 equivalent of methylester phenolic phosphine 2a (synthesized as shown in Scheme 2) and heated for $4 \mathrm{~h}$ at $70^{\circ} \mathrm{C}$ followed by the addition of water and $2 \mathrm{~h}$ of stirring at $70^{\circ} \mathrm{C}$, the full conversion of the starting dinucleotide was observed (Scheme 1, entry 1 ). These conditions lead to the formation of the ligated compound $4 \mathrm{a}$ in $22 \%$ yield in competition with the reduced derivative 6 . In addition, a cyclic oxazaphospholane derivative 5 a was obtained in $28 \%$ yield. Evidence for the formation of compound $5 \mathbf{a}$ was gathered by monitoring the reaction by ${ }^{31} \mathrm{P}$ NMR spectroscopy (See supporting information S70). After 55 min of reaction in $\mathrm{DMF} / \mathrm{D}_{2} \mathrm{O}(9 / 1, \mathrm{v} / \mathrm{v})$, a growing signal at +40.6 ppm was observed compared to the characteristic peak of the phosphine $2 \mathrm{a}$ at $-15.8 \mathrm{ppm}$ and occurrence of oxidized species. The formation of such cyclic derivative could be explained by the 1,2-cis position ${ }^{22}$ of the 2'- $\mathrm{N}_{3}$ function and the 3'-OH hydroxyl on the ribose. The modification of the reaction conditions with a longer reaction time or irradiation under micro-waves did not allow to increase the yield of the ligated compound $\mathbf{4 a}$ and dramatically increased the formation of the oxazaphospholane 5a (See supporting information S56).

Scheme 1. Reaction of dinucleotide 1 with-phenolic ester $\mathbf{2 a}$ and alkyl thioester 3 substituted with a methyl group.
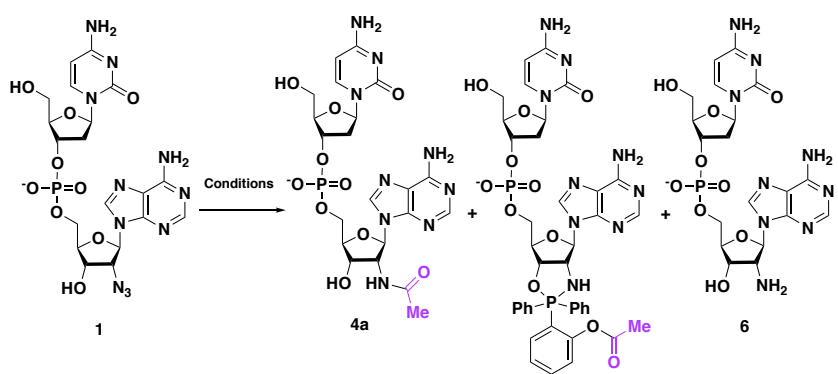

$5 a$

\begin{tabular}{|cccccc|}
\hline Entry & Phosphine $^{\mathrm{a}}$ & Conditions & $\mathbf{4 a ^ { \mathrm { b } }}$ & $5 \mathrm{a}^{\mathrm{b}}$ & $6^{\mathrm{b}}$ \\
\hline
\end{tabular}

${ }^{a}$ Using 10 equivalent of phosphine. ${ }^{b}$ Product yield based on relative integration in HPLC at $254 \mathrm{~nm}$.

We next performed the same ligation from the dinucleotide 1 with the alkyl thioester phosphine $\mathbf{3}$ (the commercially available (diphenylphosphino)methanethiol) described by Raines. ${ }^{13}$ Treatment with DABCO was first applied to remove the borohydride group which prevented the oxidation of the phosphine. In this latter condition, the cyclic oxazaphospholane derivative 5 a was not observed in the reaction mixture. The reduced compound $\mathbf{6}$ was obtained as the major product (77\% yield), whereas the expected dinucleotide $4 \mathbf{a}$ was formed in $23 \%$ yield (Scheme 1, entry 2).
To expand the scope of the reaction, we selected the phosphine phenolic ester derivatives due to their stability and easy functionalization. A range of substituted phosphines was synthetized by coupling the commercially available 2-hydroxyphenyl diphenylphosphine with the corresponding carboxylic acid in presence of DCC and DMAP in DCM at room temperature for $16 \mathrm{~h}$. Eight phosphines were obtained in 18 to $95 \%$ yield (Scheme 2 ).

Scheme 2. Synthesis of phosphines 2a-h.
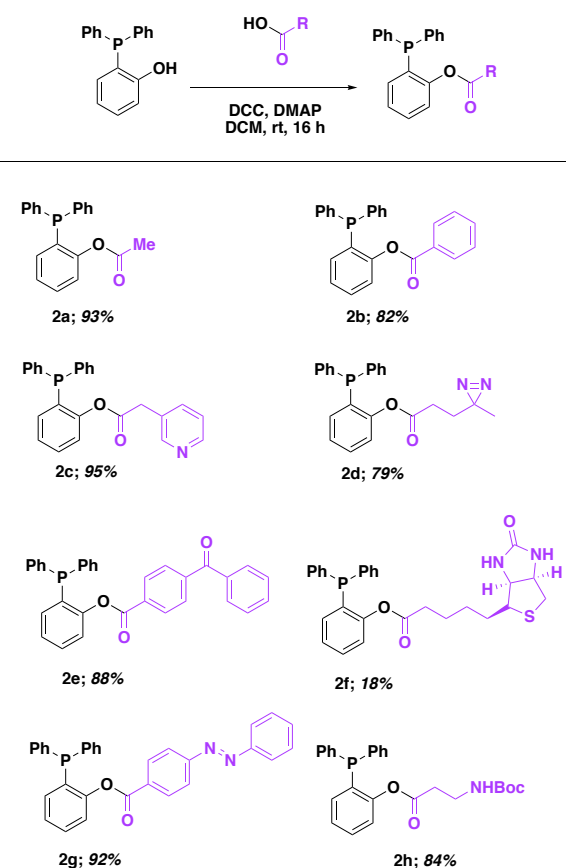

Phosphine $\mathbf{2} \mathbf{j}$ containing a sydnone substituent, recently reported as a suitable partner for click and release experiments for bioconjugation, ${ }^{4,23}$ was synthesized according to the synthetic route described in Scheme 3. Iminosydnone 7 was prepared following standard procedure $^{23}$ and activated by a 2 -step strategy ${ }^{24}$ to afford the corresponding carbonyl-imidazolium salt $\mathbf{8}$ in $75 \%$ yield. The sydnone compound $\mathbf{8}$ was then treated in the presence of DIPEA and unprotected phosphine $2 \mathbf{i}$ in DCM to lead to the phosphine $2 \mathbf{j}$ in $54 \%$ yield.

Scheme 3. Synthesis of phosphine $\mathbf{2 j}$.

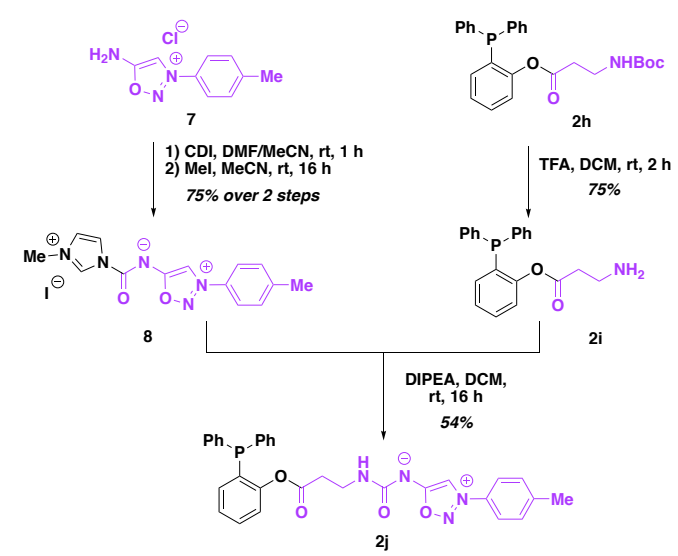

Phosphines 2a-j containing representative functionalities were submitted to ligation conditions (Scheme 4). 
Scheme 4. Substrate scope.
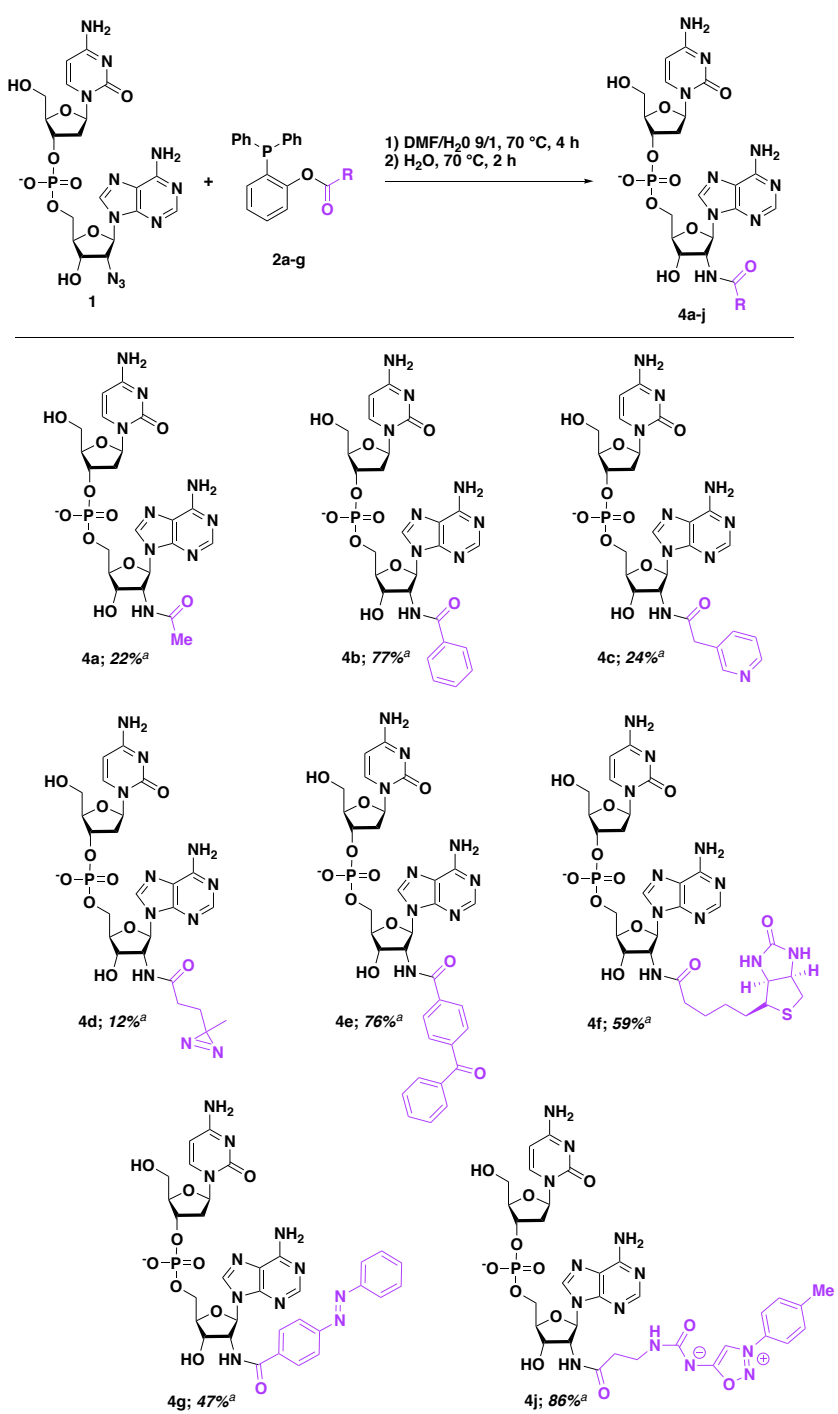

${ }^{a}$ Product yield based on relative integration in HPLC at $254 \mathrm{~nm}$.

When phosphine-containing phenyl or pyridine rings (2b, 2c) were used for bioconjugation reaction with dinucleotide 1 , compounds $\mathbf{4 b}$ and $4 \mathrm{c}$ were obtained in $77 \%$ and $24 \%$ yield respectively. Photoactivable dinucleotides $4 \mathrm{~d}$ and $4 \mathrm{e}$ have been prepared in $12 \%$ and $76 \%$ yield, respectively, using phosphine $2 \mathrm{~d}^{25}$ and $2 \mathrm{e}$. A biotin moiety, used for analysis and purification of biomolecules, was introduced in the 2'-position of the terminal ribose, in 59\% yield. A photoswitch tag has also been ligated and diazobenzene phosphine $\mathbf{2} \mathrm{g}$ led to the formation of the corresponding modified dinucleotide $\mathbf{4 g}$ in $47 \%$ yield. The ligation was then applied to access to the dinucleotide-sydnone conjugate $4 \mathrm{j}$ in $86 \%$ yield. These results show that the functionalization in 2'-position of the terminal ribose of an unprotected dinucleotide is compatible with ester phenolic phosphine containing a variety of tags. ${ }^{26}$

To go further, we applied this reaction to post-functionalize a 24-nt RNA containing an azido group at 2'-position of the terminal ribose. The 2'-azido-RNA 10 was obtained by enzymatic ligation of dinucleotide 9 (pdCpA-2'- $\left.\mathrm{N}_{3}\right)^{27}$ to a 22-nt RNA using the T4 RNA ligase RNA molecule (See supporting information S14). The sequence of the RNA has been chosen to mimic the acceptor arm of Ala-tRNA ${ }^{\mathrm{Ala}}$. The oligonucleotide 10 was then treated by an excess of phosphine $2 \mathrm{e}$ (100 equiv.) containing a benzophenone tag. After $4 \mathrm{~h}$ stirring at $70{ }^{\circ} \mathrm{C}$ in a $9 / 1$ mixture of DMF and water, followed by the addition of water and $2 \mathrm{~h}$ stirring at $70{ }^{\circ} \mathrm{C}$, the reaction lead to the formation of the functionalized RNA 11 in 7\% yield (Scheme 5). This was confirmed by mass spectrometry (MALDI analysis, See supporting information S66-69).

Scheme 5. Bioconjugation of 24nt-RNA.
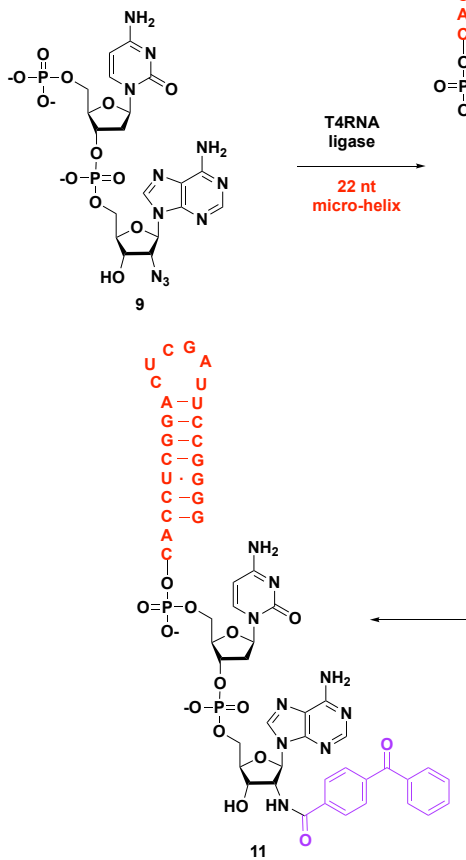

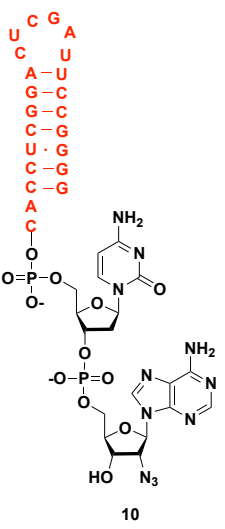

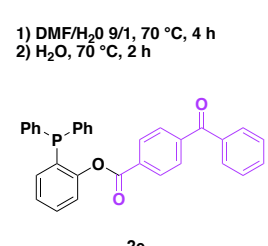

A putative mechanism accounting for our experimental results is proposed in Scheme 6. After formation of the iminophosphorane intermediate I, Staudinger reduction could lead directly to the formation of 2'- $\mathrm{NH}_{2}$ dinucleotide II. This reaction occurred in competition with the acyl transfer from the phosphine to the nitrogen of the iminophosphorane (pathway A). This step is promoted by the sixmembered ring formed during the transition state. Intermediate III could then be hydrolyzed affording the expected ligation product IV. Moreover, the nitrogen of the iminophosphorane and the hydroxyl at the 3' position were in the cis configuration, which favored the ring-closing step (pathway B) and gave access to the oxazaphospholane intermediate $\mathbf{V}$. This reactivity was reported by Bernardi and co-workers, who investigated the traceless ligation of glycofuranosyl azides. ${ }^{22}$ Triaryliminophosphorane moiety ${ }^{28}$ could promote the deprotonation of the alcohol at the 3'-position and favor the nucleophilic attack of the phosphorus. Then, the hydrolysis of $\mathbf{V}$ could provide reduced compound II and the oxidized phosphine. 
Scheme 6. Proposed mechanism.

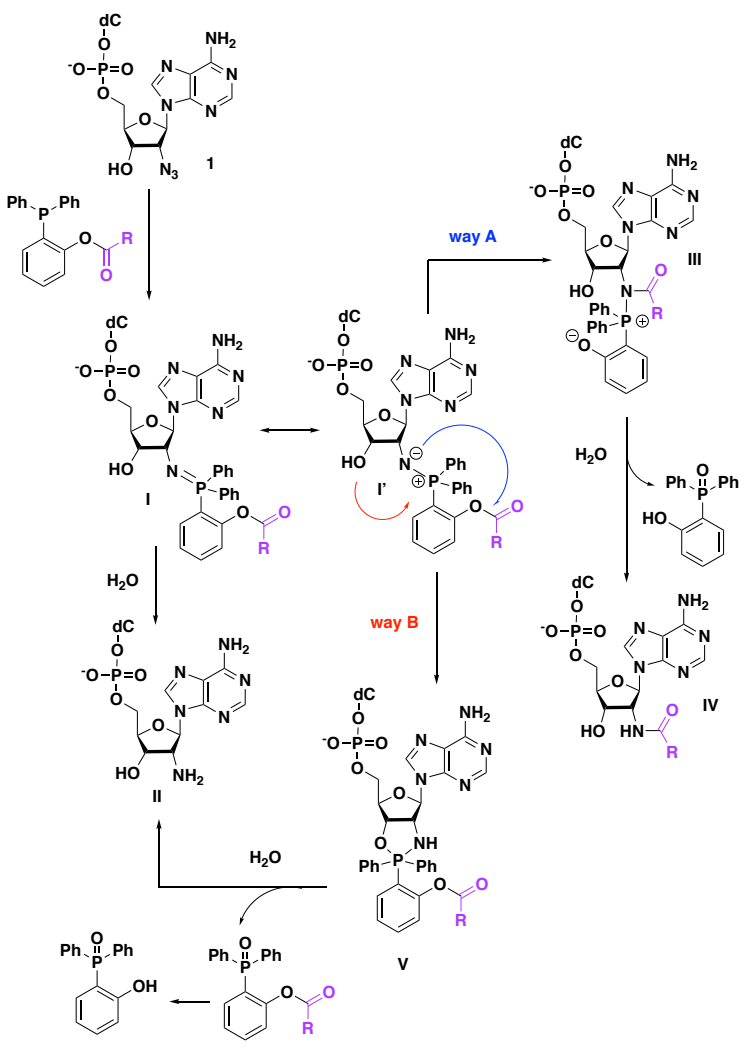

In conclusion, we have reported the first application of the traceless Staudinger ligation to the post-functionalization of RNA. We synthesized a series of ester phenylphosphines, which contained a variety of tags, such as a Biotin, photoswitch and photoactivable moieties, and a sydnone. We studied the traceless variant of the Staudinger ligation on a model dinucleotide and showed that the reaction provided moderate to good yields, depending on the nature of the ester-phenyl phosphine. We extended this methodology for the bioconjugation of a 24nt RNA strand with a photoactivable benzophenone probe.

\section{ASSOCIATED CONTENT}

\section{Supporting Information}

The Supporting Information is available free of charge on the ACS Publications website.

Characterization of phosphines 2a-i (PDF)

Synthesis and characterization of phosphine $2 \mathbf{j}$ (PDF)

Synthesis and characterization of dinucleotide 1 (PDF)

Synthesis and characterization of dinucleotide 9 (PDF)

NMR spectra (PDF)

LCMS analyses (PDF)

FAIR Data is available as Supporting Information for Publication and includes the primary NMR FID files for compounds $1,2 a, 2 b, 2 c, 2 d, 2 e$, $2 \mathrm{f}, 2 \mathrm{~g}, 2 \mathrm{~h}, 2 \mathrm{i}, 2 \mathrm{j}, 7,9$ and N-Boc- $\beta$-Ala

\section{AUTHOR INFORMATION}

\section{Corresponding Author}

*E-mail: laura.iannazzo@parisdescartes.fr; Phone: (33) 1765342 50;

*E-mail: melanie.etheve-quelquejeu@parisdescartes.fr; Phone: (33) 1 76534222.

\section{ACKNOWLEDGMENT}

This research was funded by grants from the Agence National de la Recherche (ANR), Project SyntRNA [ANR-17-CE07-0041-02].

\section{REFERENCES}

(1) (a) Lang, K.; Chin, J. W. ACS Chem. Biol. 2014, 9, 16-20. (b) Spicer, C. D.; Davis, B. G. Nat. Comm. 2014, 5, 4740.

(2) (a) Mahal, L. K.; Yarema, K. J.; Bertozzi, C. R. Science 1997, 276, $1125-$ 1128. (b) Carrico, I. S.; Carlson, B. L.; Bertozzi, C. R. Nat. Chem. Biol. 2007, 3, 321-322. (c) Kalia, J.; Raines, R. T. Angew. Chem. Int. Ed. 2008, 47, 75237526. (d) Flavell, R. R.; Kothari, P.; Bar-Dagan, M.; Synan, M.; Vallabhajosula, S.; Friedman, J. M.; Muir, T. W.; Ceccarini, G. J. Am. Chem. Soc. 2008, 130, 9106-9112.

(3) (a) Rostovtsev, V. V.; Green, L. G.; Fokin, V. V.; Sharpless, K. B. Angew. Chem. Int. Ed. 2002, 41, 2596-2599. (b) Tornoe, C. W.; Christensen, C.; Meldal, J. M. J. Org. Chem. 2002, 67, 3057-3064. (c) Kee, J. M.; Bernardes, G. J. L.; Rohde, J. U; Choe, W.; Hong, S. Y. J. Am. Chem. Soc. 2017, 139, 12121-12124.

(4) Decuypere, E.; Plougastel, L.; Audisio, D.; Taran, F. Chem.Commun., 2017, 53, 11515-11527.

(5) (a) Chalker, J. M.; Wood, C. S. C.; Davis, B. G. J. Am. Chem. Soc. 2009, 131, 16346-16347. (b) Bisseret, P.; Abdelkafi, H.; Blanchard, N.Chem. Sci. 2018, 9, 5132-5144. (c) Walunj, M. B.; Tanpure, A. A.; Srivatsan, S. G. Nucleic Acids Research, 2018, 46, e65. (d) Zhang, C.; Vinogradova, E. V.; Spokoyny, A. M.; Buchwald, S. L.; Pentelute B. L. Angew. Chem. Int. Ed. 2019, 58, 4810-4839.

(6) Agard, N. J.; Prescher, J. A.; Bertozzi, C. R. J. Am. Chem. Soc. 2004, 126, 15046-15047.

(7) Blackman, M. L.; Royzen, M.; Fox, J. M. J. Am. Chem. Soc. 2008, 130, 13518-13519.

(8) Wang, J.; Zhang, W.; Song, W.; Wang, Y.; Yu, Z.; Li, J.; Wu, M.; Wang, L.; Zang, J.; Lin, Q. J. Am. Chem. Soc. 2010, 132, 14812-14818.

(9) (a) Dawson, P. E.; Muir, T. W.; Clarklewis, I.; Kent, S. B. H. Science 1994, 266, 776-779.(b) Shin, Y;. Winans, K. A.; Backes, B. J.; Kent, S. B. H.; Ellman, J. A.; Bertozzi, C. R. J. Am. Chem. Soc. 1999, 121, 11684-11689. (c) Johnson, E. C. B.; Kent, S. B. H. J. Am. Chem. Soc. 2005, 128, 6640-6646.

(10) (a) Saxon, E.; Bertozzi, C. R. Science 2000, 287, 2007-2010. (d) Wang Z.P A.; Tian, C. L.; Zheng, J. S. RSC Adv., 2015, 5, 107192-107199. (c) Bednarek, C.; Wehl, I.; Jung, N.; Schepers, U.; Brase, S. Chem. Rev. 2020, 120, 4301-4354.

(11) Nilsson, B. L.; Kiessling, L.; Raines, R. T. Org. Lett. 2000, 2, 1939-1941. (12) Saxon, E.; Armstrong, J. I.; Bertozzi, C. R. Org. Lett. 2000, 2, 21412143.

(13)(a) Nilsson, B. L.; Kiessling, L.; Raines, R. T. Org. Lett. 2001, 3, 9-12. (b) Soellner, M. B.; Tam, A.; Raines, R. T. J. Org. Chem. 2006, 71, 98249830. (c) Tam, A.; Soellner, M. B.; Raines, R. T. J. Am. Chem.Soc. 2007, 129, 11421-11430. (d) Tam, A.; Soellner, M. B.; Raines, R. T. Org. Biomol. Chem. 2008, 6, 1173-1175.

(14) (a) Grandjean, C.; Boutonnier, A.; Guerreiro, C.; Fournier, J. M.; Mullard, L. A. J. Org. Chem. 2005, 70,7123-7132. (b) Bianchi, A.; Bernardi, A. J. Org. Chem. 2006, 71, 12, 4565-4577. (c) Nisic, F.; Andreini, M.; Bernardi, A. Eur. J. Org. Chem. 2009, 5744-5751. (d) Liu, S.; Edgar, K. J. Biomacromolecules 2015, 16,2556-2571. (e) Zhu, S.; Guo, Z. Org. Lett. 2017, 19, 3063-3066.

(15) Yamashita, T.; Kuranaga, T.; Inoue, M. Org. Lett. 2015, 17, 2170-2173. (16) (a) Tam, A.; Raines, R. T. Methods Enzymol. 2009, 462, 25-44. (b) Bernardes ,G. J. L.; Linderoth, L.; Doores, K. J.; Boutireira, O.; Davis, B. G. ChemBioChem, 2011, 12, 1383-1386. (c) Wang, Z. A.; Kurra, Y.; Wang, X.; Zeng, Y.; Lee, Y. J.; Sharma, V.; Lin, H.; Dai, S. Y. Angew. Chem. Int. Ed. 2017, 56, $1643-1647$

(17) Charafeddine, A.; Dayoub, W.; Chapuit, H.; Strazewski, P. Chem. Eur. J. 2007, 13, 5566-5584.

(18) (a) I. Kosiova, A. Janicova, P. Kois, Belstein J. Org. Chem. 2006, 2, 23. (b) Aigner, M.; Hartl, M.; Fauster, K.; Steger, J.; Bister, K.; Micura, R. ChemBioChem, 2011, 12, 47-51. (c) Yu, H.; Zheng, J.; Yang, S.; Asiri, A. M.; 
Alamry, K. A.; Sun, M.; Zhang, K.; Wang, S.; Yang, R. Talanta, 2018,178, 282-286.

(19) Weisbrod, S. H.; Marx, A. Chem. Commun. 2007, 1828-1830.

(20) Chemama, M.; Fonvielle, M.; Villet, R.; Arthur, M.; Valery, J.M.; Etheve-Quelquejeu, M. J. Am. Chem. Soc. 2007, 129, 12642-12643.

(21) Wang, Z. P. A.; Tian, C. L.; Zheng, J. S. $R S C A d v .2015$, 5, $107192-$ 107199.

(22) Nisic, F.; Speciale, G.; Bernardi, A. Chem. Eur. J. 2012, 18, 6895-6906. (23) Riomet, M.; Decuypere, E., Porte, K. ; Bernard, K. ; Plougastel, L. ; Kolodych, S.; Audisio, D.; Taran, F. Chem. Eur.J. 2018, 24, 8535-8541.

(24) Riomet, M., Porte, K., Madegard, L., Thuery, P., Audisio, D., Taran, F. Org. Lett. 2020, 22, 2403-2408.

(25). Ahad, A. M.; Jensen, S. M.; Jewett. J. C. Org. Lett. 2013, 15, 5060-5063. (26) The use of a 2'-deoxynucleoside is recommended on the penultimate position to avoid the break of the phosphodiester bridge, probably triggered by the formation of the oxazaphospholane (See supporting information S68)

(27) Fonvielle, M.; Mellal, D.; Patin, D.; Lecerf, M.; Blanot, D.; Bouhss, A.; Santarem, M.; Mengin-Lecreulx, D.; Sollogoub, M.; Arthur, M.; EtheveQuelquejeu, M. Chem. Eur.J. 2013, 19, 1357-1363.

(28) Nunez, M. G.; Farley, A. J.; Dixon, D. J. J. Am. Chem. Soc. 2013, 135, 16348-16351. 